\title{
Disease Response Assessment Date
}

National Cancer Institute

\section{Source}

National Cancer Institute. Disease Response Assessment Date. NCI Thesaurus. Code C162174.

The date on which a disease response assessment is completed. 